\title{
WHEN LIFE GIVES YOU LAW, MAKE LEMONADE: EXPLORING THE ‘LEGALISED’ OPPRESSION OF BLACK WOMEN IN THE UNITED STATES OF AMERICA AND SOUTH AFRICA AND THEIR MUSICAL RESPONSE THERETO
}

\section{Introduction - Overture}

'Oppression' can take a great number of forms, depending on its context, purpose and subjects. The forms of oppression which are the subject of this article are racial prejudice and patriarchy. These two forms of oppression are relevant here to the extent that they are imposed on Black women. Within this context, the struggle of Black women is twofold, in that it is comprised of the Black person's struggle, against racial prejudice, as well as the woman's struggle, against patriarchy. Additionally, this struggle, against racial prejudice and patriarchy, is also twofold in the sense that it exists in society and is also condoned by the law. Therefore, the racial prejudice will be

* $\quad$ BA (Law), LLB and LLM (Human Rights and Democratisation in Africa), University of Pretoria; Diploma (Justiciability of ESCR), Åbo Akademi University. Doctoral Candidate and Researcher in the Children's Rights Project at the Dullah Omar Institute, University of the Western Cape. Email: tkhoza@uwc.ac.za. ORCID: 0000-0001-6107-5290. The author extends her gratitude to her dear friend Ndabo Zulu for his assistance with parts of Suite III; thank you for lending me your ear, Mageba. 
discussed as it relates to the Blackness of Black women and the patriarchal prejudice will be discussed as it relates to the 'womanness' of Black women.

This paper, then, recalls the racial and patriarchal oppression of the Black woman by looking at the said oppressions as they have existed in society as well as some ways in which the law has aided or reinforced them. Once the oppressions, their existence and legal enforcement, have been outlined, this paper then visits the topic of music as a documentation of and escape from the experience of these oppressions by Black women. It should also be noted that, due to similarities which will be outlined in the article, the focus of this paper is squarely on the experience of the Black woman in the United States of America (USA) and South Africa. Therefore, some racially prejudicial laws will be sampled from these countries. Furthermore, some music by Black female artists from both countries will be sampled too. Above all, this article is presented as a reminder of sorts that the law does not exist in a vacuum - it applies to, has consequences for and is experienced by people.

\section{SUITE I: A synopsis of racial prejudice against the black person in the United States of America (USA) and South Africa}

As already alluded to in the introduction, the first form of oppression experienced by the Black woman in the USA and in South Africa takes the form of racial prejudice. To say that the racial prejudice which is presently experienced by Black women in the USA and South Africa is not new, it is old and persistent, would not be an exaggeration. Therefore, it is important to trace and reflect on its roots. To this end, this article will offer a synopsis of the age of slavery and the Jim Crow era, in the context of the USA. Regarding South Africa, particular attention will be paid to the segregation era and the Apartheid era. The topics of slavery and segregation will be discussed tangentially, so as to better place the Jim Crow and Apartheid eras in context. Two things should be borne in the mind for this section. Firstly, this article admits that each of these topic areas are vast and cannot be completely analysed in the space of a few words; be that as it may, it remains necessary to visit these topic areas, even if only as far as the article will allow, in order to make the article complete. Secondly, as is alluded to in the introductory section of this paper, before turning its focus to art as a coping mechanism and machine of awareness, this article focuses on the existence of the sampled prejudices as well as their reinforcement in and by the law. Therefore, these eras enumerated above are chosen because of their clearly racially prejudicial laws, the consequences of which are still persistent in today's society. 


\subsection{Movement I: The American case study}

This article begins the conversation on racial prejudice with the American case study. The Transatlantic slave trade and the practice of slavery in the United States of America need not be unpacked before its racial prejudice is exposed. ${ }^{1}$ Racial prejudice is a riff which continues through and joins every component of the trade and practice, from the capture, to the transportation, to the trade and to the use of the slaves. ${ }^{2}$ It is important to first discuss this era, then, in order to foster a more wholistic understanding of the Jim Crow era. ${ }^{3}$

The first (chattel) slaves from Africa are said to have arrived in the United States in the year 1619. ${ }^{4}$ From this time, up till the abolition of the slave trade, ${ }^{5}$ it was common practice to import and exploit slaves in what was then 'the Colonies'. 6 During this time, there were some plainly prejudicial laws which were promulgated against the slaves. The most obviously racially prejudicial was the enactment of laws which allowed Black people to be imported and exploited as slaves, without protection. 7 These Black slaves were exploited as cheap labour, it would be more accurate to call it 'free labour', and this free labour produced large quantities of materials which were in high demand all over the world such as tobacco, sugar and cotton. ${ }^{8}$ One of the most important laws enacted against them during this era was that which allowed slave masters to violently beat and kill their slaves. ${ }^{9}$ Though present during the time of slavery, the exploitation of Black people in the USA, particularly that of Black women, did not end with slavery; instead, it evolved with the years.

The consideration of legally sanctioned exploitation and free will to physically abuse or kill Black people, is important for the understanding of the, for lack of a better word, 'anxiety' amongst the White population of the United States of America which was carried over after the abolition of the slave trade. Notably, because of the racist attitudes harvested during the age of slavery, even after the

1 JP Greene 'The social origins of the American Revolution: An evaluation and an interpretation' (1973) 88 (1) Political Science Quarterly 2.

2 L Angeles 'On the causes of the African slave trade' (2013) 66 (1) KYKLOS International Review for Social Sciences 3.

3 M Rosenfeld Affirmative action and justice (1991) 96.

4 A Fede 'Legitimized violent slave abuse in the American South, 1619-1865: A case study of law and social change in six southern states' (1985) 29(2) The American Journal of Legal History 99.

5 PM Muhammad 'The Trans-Atlantic slave trade: a forgotten crime against humanity as defined by international law' (2003) 19 (4) American University International Law Review 9931.

6 Fede (n 4 above) 101 - 105.

7 BJ Nicholson 'Legal borrowing and the origins of slave law in the British Colonies' (1994) 38(1) The American Journal of Legal History 38.

8 Angeles (n 2 above) 12.

9 H Kotef 'On abstractness: first wave liberal feminism and the construction of the abstract woman' (2009) 35(3) Feminist Studies 509; Fede (n 4 above) 93. 
abolition of the slave trade, issues of affirmative action and reconstruction of society were not given attention. ${ }^{10}$

For many years, the American government preached the 'separate but equal' gospel and used this phrase to justify the segregation and oppression which Black people were subjected to during the Jim Crow era. ${ }^{11}$ However, the Jim Crow era made peoples separate and unequal. Much like the practice of the Apartheid era, Black and White people were kept separate on railroads, in education, at work and in justice. ${ }^{12}$ Regarding separation in education, it is interesting, and important, to take note of the case of Berea College $v$ Common Wealth (Berea College). ${ }^{13}$ Berea College was an institution which was privately founded and funded by an abolitionist in the 1850s. In 1904, the College admitted both Black and White learners. ${ }^{14}$ The community reacted negatively to the admission of different races to one school, and shared classes, and so the state legislature promulgated a law which stated that schools could admit both races, so long as they offered separate classes, 25 miles apart from each other, otherwise they would have to pay a hefty fine. ${ }^{15}$ Berea College approached the Kentucky Trial Court and the Kentucky Supreme Court; however, both Courts ruled in favour of the legislature and the law was upheld. ${ }^{16}$

This case was then taken to the Supreme Court, which has been said to have had some positive race cases in that era which were halted because of White public anxiety at a stage. ${ }^{17}$ The Berea College case is an example of the 'halt' in positive rulings as the Supreme Court clearly supported the segregation of education between races. ${ }^{18}$ There was great support in the public for this segregation-supportive and racially discriminatory and prejudicial case. The then President of Harvard in 1907, soon after the Supreme Court passed the judgment, expressed support for the judgement stating that it was perfectly fine and sensible because of the large number of Black students at Berea College. He went on to state that, had Harvard had more Black students, as opposed to the 30 Black students to the 5000 White students, then Harvard would have also had to have separate classes. ${ }^{19}$ At this point one would ask oneself: why would you need to segregate classes with a large number of Black

10 Rosenfeld (n 3 above) 96.

11 MJ Klarman From Jim Crow to Civil Rights (2004) 8.

12 Klarman (n 11 above) 9.

13 Berea College v. Commonwealth, 123 Ky. 209, 220-21, 94 S.W. 623, 626, (1906).

14 BC Schmidt 'Principle and prejudice: the supreme court and race in the progressive era. Part 1: The heyday of Jim Crow' (1982) 82(3) Columbia Law Review 446.

15 Schmidt (n 14 above) 446.

16 Schmidt (n 14 above) 447.

17 Schmidt (n 14 above) 445 - 446 \& 449.

18 Schmidt (n 14 above) 449.

19 Schmidt (n 14 above) 451. 
students, when you see no need to do so when there is a small number of students? This thinking shows the unfounded anxiety of the time, which was fuelled only by racial prejudice. The President's words do not make sense, they are not scientific, they are only racially prejudicial. Nonetheless, this state of events highlights the fact that societal prejudice was legitimised by the law. The Supreme Court's decision in Berea College was also hailed and supported in the legal publications such as the Outlook, Harvard Law Review and Virginia Law Register. ${ }^{20}$

The United States Supreme Court also heard dozens of other cases dealing with, and requesting it to, legitimatise racial segregation in the 'heyday of Jim Crow'. ${ }^{2}$ ' The Supreme Court's decisions in these cases resulted in the Court legitimising and enabling the Jim Crow laws and the segregation that these cases called for; thus, the Supreme Court entrenched Jim Crow laws. ${ }^{22}$ Of particular importance is the Civil Rights Act of 1875 which stated:

all persons within the jurisdiction of the United States shall be entitled to the full and equal enjoyment of the accommodations ... of inns, public conveyances on land or water, theatres and other places of public amusement ... applicable alike to citizens of every race and [colour]. ${ }^{23}$

The Supreme Court held that this Act was unconstitutional. The bench further stated that 'it would be running the slavery argument into the ground $\dddot{2}$ to view acts of private discrimination as badges of slavery'. ${ }^{24}$ The majority decision further displayed a lack of willingness for equal protection by holding:

When a man has emerged from slavery ... there must be some stage in the progress of his elevation when he takes the rank of a mere citizen, and ceases to be the special [favourite] of the law. ${ }^{25}$

The Supreme Court's stance clearly reflects the legal legitimisation of the general societal attitude which favoured racial segregation. As a result of its support for racial prejudice in its decisions, the Supreme Court gave power to the law to legitimise the racial prejudice which the Black population was subjected to. The cases discussed above highlight that there was in fact a legal legitimisation of racial prejudice against black people, which came about because of the pressures of (white) society. Therefore, simply stated, segregation along racial lines existed both in society and in law.

20 Schmidt (n 14 above) 451.

21 The Civil Rights Cases 109 U.S. 3 (1883); Plessy v Ferguson 163 U.S. 537 (1896).

22 Schmidt (n 14 above) 461.

23 Civil Rights Act of March 1, 1875, ch. 114, 18 Stat. 335 (held unconstitutional in 1883).

24 The Civil Rights Cases 109 U.S. 3 (1883) para 24.

25 The Civil Rights Cases 109 U.S. 3 (1883) para 25. 


\subsection{Movement II: The South African case study}

As stated in the introduction, regarding racial prejudice, this article focuses on the Black experience in the USA and South Africa. Having glossed over the situation in the USA, the focus of this article now turns to the subject of Apartheid as the manifestation of racial prejudice in South Africa. Once again, it is emphasised that there is more to Apartheid, it's history, structure, aims and outcomes, than can be fit into a few pages. However, in order to explain the history of the Black woman's plight, as it has been formed and shaped in South Africa, it would be remis to not discuss the Apartheid era, albeit briefly. Whereas the age of slavery and Jim Crow era were discussed above, segregation and Apartheid will be discussed below.

The history of racial oppression in South Africa stretches over hundreds of years and started in a similar way to how colonisation started in other parts of Africa. It took the West just eleven years to colonise 50 African states, out of what was then 53 states. ${ }^{26}$ However, South Africa had a different tale, in that it was tossed between two states- the Netherlands and Great Britain. ${ }^{27}$ Depending on the time in history and which part of the history you are referring to, either one of these nations could be named as the colonisers of South Africa. ${ }^{28}$ However, what sets South Africa apart is what came after the age of colonisation. While other African countries, as well as countries in other parts of the world, such as the Caribbean and Asia, gained their independence after colonisation, South Africa's independence meant independence for the Boer population. ${ }^{29}$ The transition for South Africa then became a transfer of power from one Caucasian population to another. In the beginning of the new age, segregation was kept as we understand it; however, after a while, South Africa was dragged into the dreaded 'Apartheid'. ${ }^{30}$ Apartheid took racial segregation to another level and it achieved this through the implementation of a large number of laws which validated the oppression of Black people. During the apartheid era, there were hundreds of laws which were enacted; if the legislature did not originally think of a law, once a case had been heard in court, if needed, a new law would follow, almost instantly. ${ }^{31}$

One of the most notable and long-lasting, it would seem it was actually 'everlasting', laws of the age of segregation is the Natives

$26 \mathrm{AD}$ Akinmade 'Colonial legacy and the retracted state: Africa in motionless motion' (2014) 3 (9) Journal of Arts and Humanities 60.

27 AT Farkash 'The ghosts of colonialism: economic inequity in post-apartheid South Africa' (2015) 3 Global Societies Journal 13.

28 Akinmade (n 26 above) 71.

29 Farkash (n 27 above) 14.

30 Farkash (n 27 above) 16.

31 P Maylam 'explaining the apartheid city: 20 years of South African urban historiography' (2009) 21(1) Journal of Southern African Studies 25. 
Land Act. ${ }^{32}$ This was the first major piece of segregation legislation to be passed by the Unionist Parliament. Not only that, it was also particularly notable because its contents applied to all Black people across the entire country (or as it was called then, the 'Union of South Africa' $)^{33}$ in one way or another. JBM Hertzog, the Prime Minister of the Union of South Africa from 1924 to 1939, laboured for ten years in attempts to have parliament pass a Bill which would shove the Black population onto insignificant pieces of land spotted all over the country and keep them there. After him, his successors kept this law, as it eventually became, and they intensified it too, taking Herzog's reserves and turning them into homelands. ${ }^{34}$ Although Herzog was the Prime Minister during the segregation era, his words, 'we must choose whether we want to keep the land or the native' remained the mantra all through apartheid; ${ }^{35}$ and we still see the words manifest every day.

Like in Jim Crow USA, for every act of marginalisation performed by the white communities in South Africa, there followed a law which aimed to validate that act. ${ }^{36}$ All the laws which regulated land, labour and freedom, all of which are linked, worked together for the good of the White population, at the expense of the Black population. ${ }^{37}$ For example, the Natives Land Act resulted in Black people receiving only $7.3 \%$ of the total, and the least profitable or arable, land in South Africa, made it illegal for Black people to own land, made it impossible for Black people to vote, restricted the movement of the Black population, especially in the so-called 'white areas' and secured many agricultural jobs for the White population, at the expense of Black farmers. ${ }^{38}$ All these restrictions expose the far reach of this Act.

The Natives Land Act, though particularly notable, was preceded by other Acts, such as the earlier Glen Grey Act. ${ }^{39}$ In the late 1800 s, most of the Black community, which had previously qualified for the vote because of the amount of land they owned, became disenfranchised. ${ }^{40}$ The Glen Grey District, where the Act applied, covered the areas of Queenstown and Wodehouse. In these areas, the

32 Native Lands Act No 27 of 1913.

33 South African History Online 'The Natives Land Act of 1913' 27 August 2019 https://sahistory.org.za/archives/natives-land-act-1913 (accessed 13 June 2020).

34 A Dodson 'The Natives Land Act of 1913 and its legacy' (2013) Forum 29 - 30.

35 H Giliomee The Afrikaners: biographpy of a people (2003) 308.

36 W Beinart Twentieth century South Africa (2001) 55.

37 ST Plaatje Native life in South Africa (1996) $x$.

$38 \mathrm{~N}$ Worden The making of modern South Africa: conquest, segregation and apartheid (2000) 48-49; D Oakes Illustrated history of South Africa: the real story (1989) 316.

39 Glen Grey Act 25 of 1894; For more information on the Glen Grey Act, see generally: https://omalley.nelsonmandela.org/omalley/index.pho/site/q/03lv01 538//04lv01646/05lv01705.htm (accessed 13 June 2020).

40 CC Crais White supremacy and black resistance in pre-industrial South Africa (1992) 193. 
Black population, mostly made up of abaThembu, outnumbered the White population. This caused great anxiety for the White population because, if all those Black people could vote, they would surely successfully be ruled by a candidate of their choosing. The abaThembu owned a lot of land in this area; however, they owned it communally. Therefore, in response to the White anxiety, the Glen Grey Commission was set up in 1893 and one of the suggestions made by the Commission was that the land should be split between families so that some Black people would end up without land and so have no right to vote and have to also leave the area in search for work. ${ }^{41}$ Cecil John Rhodes, along with his secretary, then drafted the Glen Grey Act in order to deal with the questions of land, labour and franchise. ${ }^{42}$ The Glen Grey Act, which had been passed some 20 years before the Natives Land Act, first limited and restricted the amount of land which could be bought by a Black family to 'one man, one plot' as well as restricted the number of people who could live on and own land; ${ }^{43}$ and then in a later amendment (1903) it also made illegal the purchase of land by anyone from the Black community. ${ }^{44}$ This is important to note because the laws, which existed at that time, gave someone a vote, only if $\mathrm{s} /$ he had a certain amount of land. Therefore, if a people could not own land, they could not vote. ${ }^{45}$

In 1887, the South African Government also passed the Parliamentary Voters Registration Act, which discounted communal land tenure from qualifying to vote. ${ }^{46}$ As a result of this, more Black people lost their right to vote. In 1882, the Franchise and Ballot Act was introduced, and it demanded that one should, in addition to holding the requisite amount and type of land, be able to sign his or her own name in order to be allowed to vote. ${ }^{47}$ Again, more Black people lost their right to vote. The idea of reserves, though extended in the Natives Land Act, was also first contemplated only for the area of Natal, within the Lagden Commission Report of $1903 .{ }^{48}$ Collectively, all these laws highlight the legalisation of racial prejudice as well as establishes it as a recurring theme in the law.

Different laws governed different peoples in different ways because the country South Africa did not exist until it was first constituted as the Union of South Africa through the South Africa Act of 1909 , which was adopted by the British Parliament after the two

41 South African History Online (n 33 above).

42 South African History Online (n 33 above).

43 Glen Grey Act of 1884 clause 26.

44 Glen Grey Act of 1884 clause 26.

45 Worden (n 38 above) 48.

46 South African History Online (n 33 above).

47 South African History Online (n 33 above).

48 MA Ishangi 'The Origin of Segregation and the Existence Thereof by 1910' 27 October 2015 https://earlyengagements.wordpress.com/tag/lagdencommission/ (accessed 13 June 2020). 
Anglo-Boer Wars. ${ }^{49}$ By the time the Union was formed, only some Black people in the Cape Colony had the right to vote, ${ }^{50}$ subject to the fulfilment of the conditions mentioned above. ${ }^{51}$ The colour bar on the right to franchise in the rest of the land, as well as the protection of the remaining Black vote, was transposed into the Act which constituted the Union, ${ }^{52}$ and it could only be changed by a two thirds majority vote in parliament. ${ }^{53}$ The Natives Land Act would have stripped the Cape Black voters of their right, if it had not been for a judicial decision which barred its operation in the Cape Colony. By disallowing Black people from purchasing land outside the designated reserves, they would not be able to satisfy the property qualification set in the South African Act of 1909; therefore, they would no longer be able to vote. ${ }^{54}$ It should be mentioned here that the government finally got the two third majority to strip all Black people of the right to vote through the successful adoption of the Native Representation Act in $1936 .{ }^{55}$

It is also important to mention that the Natives Land Act had a twin, the Pass Laws of February 1913. ${ }^{56}$ These two laws worked together to ensure that the movement of Black folk was regulated and restricted, no matter where they found themselves in South Africa. Pass laws, which lasted right through apartheid, ${ }^{57}$ meant that the White population maintained control of the movements of the Black population at all times. ${ }^{58}$ If a Black person was found without a pass or found in a white area during a time by which s/he had to be gone, the consequence, in the best-case scenario, would be imprisonment. ${ }^{59}$ This is a reflection of white anxiety, as it was borne from the Natives Land Act, and its consequences on the Black body and freedom of movement.

The Apartheid era was then borne after the successful legal racial discrimination victories of the late segregation era. Apartheid was based on four main ideas: the categorisation of four racial groups, namely, Black, Coloured, Indian and White; the establishment of the White race as the 'civilised race' which was entitled to the absolute

K Skovsholm 'The Right to vote in South Africa - a hundred years of experience' (1999) 32(2) Verfassung und recht in übersee / law and politics in Africa, Asia and Latin America 237.

50 Skovsholm (n 49 above) 238.

51 See discussion in notes 39 to 45 .

52 Skovsholm (n 49 above) 238.

53 South Africa Act of $1909 \mathrm{sec} 35$; Skovsholm (n 49 above) 239.

54 L Thompson A History of South Africa (1990) 163.

55 Skovsholm (n 49 above) 239.

56 Pass Laws of 1913.

57 Notably, the apartheid government promulgated the Abolition of Passes and Coordination of Documents Act No 67 of 1952 as its inaugural law which would regulate the movement of the black population by making it law for them to carry a form of identity book whenever moving outside of their reserves.

58 Crais (n 40 above) 194.

59 Maylam (n 31 above) 20. 
control of the state; the greater consideration of White interests at the cost and ignoration of Black interests and; keeping the White population in 'South Africa' and the Black population in the 'reserves', which would soon become the 'homelands. ${ }^{60}$ In order to create parliamentary supremacy, the Apartheid government passed and used a number of laws to create a larger senate and larger Court of Appeals, both with majority Afrikaner members, who would in turn vote in or rule in favour of laws which gave parliament the power to further reinstate racial discrimination. ${ }^{6}$

There are similarities to be found between the United States' Civil Law Act, as amended after the Civil Law Cases decision, and South Africa's Pass Laws. Both restricted the public movement of the Black population and legislated the community sanctioned racial segregation. Besides the carrying over of laws of segregation and limited movement from the age of segregation to the Apartheid era, it is also worth noting that the Apartheid government further restricted relations between races, through the promulgation of the Mixed Marriages Act and the Immorality Amendment Act. ${ }^{62}$ These two acts forbade interracial marriages and interracial sexual relations, respectively. Similarly, the United States had such laws regulating romantic relations.

The discussion of the selected laws of segregation and discrimination highlights the presence and irrationality of these laws. Furthermore, the discussion, hopefully, also nudges one to consider the relevance and persistence of the consequences of these laws within the current status quo. Racial prejudice still exists, perhaps not so blatantly in the law, but definitely within society. Therefore, the current status quo both establishes as well as emphasises the existence of a bidirectional relationship between societal attitudes of racial prejudice and the legal legitimisation thereof. Whereas a century and some decades ago it was the attitudes of society which informed the law, it is now more often the past laws which inform the societal attitudes of racial prejudice. That is the beauty and, in this case, danger of the law - its impact and consequence on people is often long-lasting, whether intended to be so or not.

\section{SUITE II: Black feminist thought}

Having discussed the racial prejudice afflicted on Black women, the paper now turns to a discussion of the intersectionality of racial and patriarchal prejudice. Regarding patriarchal oppression, although it is not discussed here, it should be mentioned that the feminist school of

60 Skovsholm (n 49 above) 190.

61 Skovsholm (n 49 above) 241 - 242.

62 Mixed Marriages Act 55 of 1949; Immorality Amendment Act 21 of 1950. 
thought took many forms and morphed a few times over the years, so as to include more issues. Evolution notwithstanding, however, Black Feminist Thought was formed as a direct response to all of the oppressions suffered and experienced by Black women. Again, the feminist school of thought is a kaleidoscope all the contents of which cannot be discussed within a few pages. Even on its own, the Black Feminist Thought strain is also a discussion which can fill books. Thus, in order to further contextualise the music sampled in the following section, this paper will only discuss some themes of Black Feminist Thought. The (mainstream) feminist movement(s) oftentimes excluded Black women. As a result of this exclusion, based on the shared oppression of Black women and understanding thereof, came Black feminist activist tradition. ${ }^{63}$ This section, therefore, aims to highlights some arguments and stances regarding the Black Feminist reaction to the exclusion from 'mainstream' or 'White' feminism as well as the formulation of Black Feminist Thought.

Although also reacting to patriarchal oppression, the mainstream feminism excluded Black women by not engaging with their specific experience. This is not surprising as it is possible for a people to be both the oppressed and the oppressors in different settings yet simultaneously. ${ }^{64}$ Black women, as an 'intersectionally oppressed' group, in America, but also similarly in other parts of the world, ${ }^{65}$ have felt 'between the loyalties that bind them to race on one hand, and sex on the other. ${ }^{66}$ Their call for their rights has often been regarded as a threat to the unity of the community and as being harmful to the common struggle, both in White feminist spaces and in Black critical race theories spaces. ${ }^{67}$

A conversation on mainstream feminism often refers to 'waves' of feminism. One of the reactions to mainstream feminism(s) has been to aver that the wave model of feminism inherently excluded women of colour, both from the history of women's movements as well as feminist theory. ${ }^{68}$ This, it is argued, was manifested in the style of the white mainstream movement to ignore the economic and survival issues which were occupying Black Feminist Thought. ${ }^{69}$ As a result of the exclusion within the space of (White) feminism, then, Black

63 P Hill Collins 'The social construction of black feminist thought' (1989) 14(4) Journal of Women in Culture and Society 746.

64 M Alinia 'On black feminist thought: thinking oppression and resistance through intersectional paradigm' (2015) 38(13) Ethnic and Racial Studies 2335.

65 Alinia (n 64 above) 2336 \& N McKay 'Remembering Anita Hill and Clarence Thomas: what really happened when one black woman spoke out' in T Morrison (ed) Race-ing Justice, En-gendering Power (1992) 277 - 278

66 McKay (n 65 above) 277 - 278.

67 Alinia (n 64 above) 2336.

68 K Springer 'Third wave black feminism?' (2002) 27(4) The University of Chicago Press 1063.

69 B Roth 'Second wave black feminism in the African diaspora: news from new scholarship' (2003) 17(58) Agenda 48. 
women curated their own feminism, which placed them and their experiences at the centre. When following the argument that the waves construct excluded Black women, it would not follow that Black feminism came at the end of the second or third wave of feminism. To this end, Roth, while talking about the Second Wave, aptly writes, 'Black women formed feminist groups despite a political climate that asked them to choose between fighting racism or sexism'. ${ }^{70}$ In the same vain, Hill Collins notes that, 'Black women carried a special burden - not only were they Black, poor and second-class citizens, but they were female as well. 71 This additional 'special burden' and the intersectional issues peculiar to Black women highlight both their exclusion from the waves of white feminism as well as the difference in their struggle

Alinia posits that Black Feminist Thought developed 'through a dynamic interaction with black women's everyday struggles'. ${ }^{72}$ Furthermore, it is not only a method of viewing, constructing or deconstructing social realities; rather, it is a 'way of life and living in general.'73 When constructing a theory, the infusion of the experience of the group for whom the theory is being constructed is central, it cannot be neglected. ${ }^{74}$ Therefore, the experience of the Black woman is central to Black Feminist Theory and other theoretical modes (of Black men and White women, who are often both oppressors and oppressed) do not pay sufficient attention to the reality of the Black woman's experience. As a result of this, the theoretical modes of these groups have gaps, in the case of the Black woman, because the Black man's and White woman's experiences are only a part of the Black woman's experience. ${ }^{75}$ Because of this paucity, Black Feminists have asserted that nobody but them can speak for them. To this end, Amoah writes that 'neither white women's experience of sexism nor Black men's experience of racism alone, nor simply adding these two together, is equivalent to Black women's experience of both. ${ }^{76}$ Smith posits that 'such a formulation erases the specificity of black women's experience, constituting her as a point of intersection between black men's and white women's experience. ${ }^{, 77}$

70 Roth (n 69 above) 46.

71 P Hill Collins 'Gender, black feminism, and black political economy' (2000) 568 The Annals of the American Academy 42.

72 Alinia (n 64 above) 2334.

73 J Amoah 'Narrative: the road to black feminist theory' (1997) 12(1) Berkley Women's Law Journal 97.

74 Amoah (n 73 above) 85.

75 Amoah (n 73 above) 98.

76 Amoah (n 73 above) 98.

77 V smith "Black feminist theory and representation of the "other"' in CA Wall (ed) Changing our own words: Essays on criticism, theory and writings by black women (1989) 47. 
Black Feminist Thought, which was similar to but more sophisticated than the Third Wave, had interconnection, rather, 'intersectionality' of issues at its core. Black Feminist Theory includes 'a way of reading inscriptions of race ..., gender ..., and class in modes of cultural expression."78 Black Feminist Thought makes use of intersectional analysis in order to shed light on the 'relationships between the structural, symbolic and everyday aspects of domination and individual and collective struggles in various domains of social life'. ${ }^{79}$ It thus concerns itself with the intersectionality between race, class, nation and gender, all of which are important for and to the Black woman. ${ }^{80}$ Furthermore, as opposed to the examination of the themes of race, gender, class and nation as separate systems of oppression, intersectionality is constructed in order to reference the manner in which these systems 'mutually construct one another'. 81 Intersectionality implies that a person is never discriminated against based on just one of their qualities. ${ }^{82}$ Also, Black Feminist Thought was a 'For Us by Us' construct which, importantly, noted that the resistance generated by Black women was from their daily experiences, which were different to those of the 'mainstream' feminists, especially as they regard the 'interlocking systems of race, class, gender and sexuality in Black women's lives'. ${ }^{3}$

On the issue of Black women and feminism, it should be noted that, regrettably, the history of 'third world feminism' is not recorded as extensively as the history of 'first world feminism'. One argument which has been advanced is that, recording such history, which expresses the activism of Black women in Africa, would be 'going against the grain of history'. ${ }^{84}$ This is actually true for most third world and, more specifically, black history. For a long time, Africa was known as 'the dark continent' which did not have its own history because African history was not scribed in the same way that Europeans wrote theirs. So, simply put, a history or record of women of colour being strong could not be exposed alongside a history which painted them as weak or subordinate. Thus, the history of imperialism, oppression and colonialism and, where allowed, the strength of White women, was recorded and disseminated while the history of the strength of Black women was concealed. This links in with the 'traditional' definition of third world women. Traditionally, in the white community, women of colour have been defined in terms of, or within the context of, underdevelopment, oppressive

80 Hill Collins (n 71 above) 44.

81 Hill Collins (n 71 above) 48.

$82 \mathrm{H}$ Barnett Introduction to feminist jurisprudence (1998) 7.

83 Roth (n 69 above) 46 - 47.

84 CT Mohanty et al (eds) Third world women and the politics of feminism (1991) $3-4$. 
traditions, illiteracy and poverty. This stance has been held regarding women in Africa, Asia, the Middle East and Latin America. ${ }^{85}$ If we take this statement and apply it to Black women of African descent in America and the Black women in South Africa, we see that such is the picture which has been painted over the years.

Importantly, because of the differences in experiences of the areas of intersectionality mentioned above for Black and White women, a feminism which spoke to the lived experiences of Black women had to be curated. This called for the placement of Black women's experiences at the centre of the analysis and interpretation frameworks which rely on intersectional paradigms. ${ }^{86}$ It should be borne in the mind, however, that the concretisation of the Black women's placement and consideration of her experiences within feminist thought do not call for her injection into already existing schools of thoughts and 'waves'. Instead, it called, and continues to call, for the curation of a paradigm formed from her views, opinions, experiences and position within society.

Having discussed the plight of the American and South African Black woman, as manifested by racial prejudice and sexism, this article, finally, will move to highlight some music made by Black women and its place in responding to oppression.

\section{SUITE III: The music written by black women in response to oppression}

As stated in the earlier sections of this article, the argument is made here that Black women made music to express the consequences of the oppressions they were subjected to, as Black people and as women. This is noted here to remind the reader that the law does not exist in a vacuum, it applies to people and they have to live out the consequences of its application. Furthermore, like the curation of Black Feminist Thought, it is argued that the making of music was a coping mechanism, and sometimes a form of protest too, for Black female artists.

\subsection{Allegro: Law and aesthetics}

Perhaps before going into a discussion of the sampled songs, it would add value to the discussion to shorty mention the similarities of and links between the law and music. Mumford notes that over the years there has been a 'lessening of subject boundaries', and as a result of this, other subjects, such as sociology, psychology and economics, 
have been transposed into discussions about and scholarship on law. ${ }^{87}$ The use of artistic language to interpret the law is called the 'aesthetic approach' to the law, and it reveals that the law, like the arts, has many layers which are open to multiple interpretations. ${ }^{88}$ To this end, Frankfurter posits that 'statutory interpretation is not a science but an art', 89 and Frank writes that 'the legislature is like a composer. It cannot be helped: It must leave interpretation to others, principally to the courts.' 90

Specifically, regarding music and the law, the two disciplines look very different on the surface; however, Levinson and Balkin hold that the study of music enables us to see things in law which were 'there all along but hidden by our very familiarity with it' ${ }^{91}$ It has also been written that music can provide metaphors for law. ${ }^{92}$ Scholars, Hibbitts writes, have interrogated the metaphor of music and law 'hoping perhaps to humanise law in the process', while others have offered 'more thought explorations of the similarities between the genres'. 93 Both the law and music have theoretical and practical aspects. ${ }^{94}$ Furthermore, both disciplines have a text to be interpreted, build on past practice and both can have political content. ${ }^{95}$

Essentially, the way in which we read music can be transposed to how we read the law. ${ }^{96}$ Music compels us to think about the meaning and power of something, the law included. ${ }^{97}$ Therefore, while the interpretation tools from music can be used in law, music itself also helps us to interrogate the law. As the author understands it, 'law and aesthetics' is about the interpretation of the law or laws in the style of literature and the arts, including music, as well as drawing our attention to the 'blurred lines' of the disciplines. This discussion is an important one; more particular to this paper is the discussion on the expression of the oppression of the law through music.

87 A Mumford 'Law and aesthetics by Adam Gearey' (2002) 29(3) Journal of Law and Society 528.

88 Mumford (n 87 above) 528 - 529.

89 J Frankfurter 'Some reflections on the reading of statutes' (1947) 47(8) Columbia Law Review 527 \& 530.

90 J Frank 'Words and music: some remarks on statutory interpretation' (1947) 47(8) Columbia Law Review 1264.

91 S Levinson \& JM Balkin 'Law, music, and other performing arts' (1991) 139(6) University of Pennsylvania Law Review 1628.

92 C Weisbrod 'Fusion folk: a comment on law and music' (1999) 20(5 - 6) Cardozo Law Review 1439.

93 BJ Hibbitts 'Making Sense of metaphors: visuality, aurality and the reconfiguration of american discourse' (1994) 6 Cardozo Law Review 327.

94 Weisbrod (n 92 above) 1441.

95 Weisbrod (n 92 above) 1442.

96 D Manderson \& D Candill 'Modes of law: music and legal theory - an interdisciplinary workshop introduction' (1995) 20(5 - 6) Cardozo Law Review 1327.

97 Manderson \& Candill (n 96 above) 1327. 


\subsection{Adagio: Sampled music by American Artists}

There are three American artists who will be discussed in this paper. Namely, these are Billie Holiday (born Eleanora Fagan on 7 April 1915, in Philadelphia, Pennsylvania), ${ }^{98}$ Nina Simone (born Eunice Kathlean Waymon on 21 February 1933, in Tryon, North Carolina) ${ }^{99}$ and Beyoncé Knowles-Carter. Billie Holiday represents the Jim Crow Era, Nina Simone represents a crossover from the Jim Crow Era to the Civil Rights Movement era and Beyoncé represents the current status quo. This vast and varied selection also highlights the continuity of the issues faced by Black women.

Holiday, who has been dubbed 'one of the most influential jazz singers of all time', 100 was originally a solo artist, though she received a number of invites to start and join bands, and her peak years were 1936-1942. ${ }^{101}$ When Holiday finally joined Artie Shaw and his band, she became the first woman of colour to sing with a white band. Of course, within the climate of the USA in the early 1900s, this was absolutely unacceptable and so this working relationship proved to be difficult. ${ }^{102}$ As a result of this, Holiday later left this band and continued as a solo artist. ${ }^{103}$

Holiday started singing in clubs at the age of 15 and first sang Strange Fruit at the age of $23 .{ }^{104}$ Of this, Pak writes, 'to great controversy, Lady Day introduced the world to the racially charged protest song "Strange Fruit". In the end, some believe it killed her. 105 Strange Fruit, which speaks about lynchings, was banned by some radio stations and rejected by Holiday's recording label too. ${ }^{106}$ Nevertheless, Holiday premiered it at the West $4^{\text {th }}$ Café Society; here, Holiday performed the song as her final number, in a completely silent room where the only light that shone was the spotlight on her face and after she finished singing the song, she disappeared when the lights went off and offered no encore. ${ }^{10 \zeta}$ The way in which she premiered

98 G Gorlinski The 100 most influential musicians of all time (2010) 205; 'Billie Holiday Biography’ 19 January 2018, updated 24 February 2020 https:// www.biography.com/musician/billie-holiday?li_source=Ll\&li_medium=mm2mrcw-biography (accessed 1 August 2020).

99 'Nina Simone Biography' 19 January 2018, updated 17 July 2019 https://www. biography.com/musician/nina-simone\#: :text=legendar\%20performer\%20Nina\% 20Simone\%20sang,"\%20and\%20"Four\%20Women (accessed 1 August 2020).

100 Gorlinski (n 98 above).

101 Gorlinski (n 98 above) 205 - 206.

102 Gorlinski (n 98 above).

103 A\&E Television Networks 'Billie Holiday Biography' 19 January 2018, updated 24 February 2020 https://www.biography.com/people/billie-holiday-9341902 (accessed 21 April 2020).

104 Gorlinski (n 98 above); E Pak 'The tragic story behind billie holiday's "strange fruit"' 5 April 2019, updated 27 July 2020 https://www.bibliography.com/news/ billie-holiday-strange-fruit?li_source=Ll\&li_medium=m2m-rcw-biography (accessed 1 August 2020).

105 Pak (n 104 above).

106 Gorlinski (n 98 above). 
this song is in itself a form of activism, which gave the audience no option but to listen and bask in the message.

When asked, Holiday shared that she did not like to sing the song but knew that she had to, and that it reminded her of her father who had died of a lung disorder at age 39, after he had been turned away from a hospital because he was black. ${ }^{108}$ Though personal to Billie Holiday, this song's message stretch farther than her experience or connection to it. White patrons at the clubs where she performed, however, had mixed and often negative emotions about the song. Federal Bureau of Narcotics Commissioner Harry Anslinger was determined to silence her and told her to stop performing the song. Upon her refusal, knowing that she used heroin, Ansingler orchestrated a drug bust which resulted in Holiday's arrest for a year. ${ }^{109}$ When she was free, she lost her licence to perform at clubs, but continued to perform (Strange Fruit too) in halls. As a result of her resistance, in 1959 when Holiday had checked herself into hospital, it is reported that Ansingler once again had her arrested and this time went further to order the doctors to no longer treat her. As a result of the halt in treatment, Holiday died. ${ }^{110}$ This chain of events shows that the law supported an act of racism. Holiday sang about the evils of that time and yet the law allowed her to be silenced, for singing.

Strange Fruit was originally a poem written by a New York school teacher by the name of Abel Meeropol. ${ }^{111}$ Holiday sets this poem to a deeply sorrowful and downhearted piano, muted trumpet and bass backing written/played in the key of $\mathrm{Bb}$ minor. The piece is slow, allowing the listener to really take in the lyrics while also setting the regretful tone which the lyrics invite. This musicality coupled with Holiday's uniquely deep and soulful voice, if you allow it to, very easily invites the listener to experience her grief as she felt it as she sang this song. The music, Holiday's voice and the piano, ironically, bring this poem to life; in fact, it is difficult to imagine anyone else could have introduced the world to this song. The opening verse of this piece goes as follows:

Southern trees bear strange fruit

Blood on the leaves, blood at the root

Black bodies swinging in the Southern breeze

Strange fruit hanging from the poplar trees. ${ }^{112}$

107 Pak (n 104 above).

108 Pak (n 104 above).

109 Pak (n 104 above).

110 Pak (n 104 above).

111 Gorlinski (n 98 above) 207.

112 B Holiday Strange Fruit (1939). 
With a simple understanding of the Jim Crow era, one can easily deduce that this piece is about lynching. The 'strange fruit' referred to here are the Black bodies which hanged from the trees, left on display as a sign of victory for White people and defeat and oppression for Black people. Specific reference is made to 'southern trees' in the piece; this makes sense as racial oppression was more intense in the southern parts of the United States. The second line is packed with innuendoes. Of course, there may be blood on the leaves, as a result of things such as a prior beating, shooting or violent hanging. However, more interesting is this reference to the blood at the roots. This launches ones imagination in the direction of Black people- with their bodies, lives, labour and blood- nourishing the soil and roots of the trees which offered shade, food, and paper for so many people, even the White people who performed the hangings.

The lyrics of the song are a lesson on the Jim Crow era and its consequence for a number of Black people. Those who performed the lynching during this era were protected by the law, which should have protected those who were being lynched. In its provocation of reflection on issues of racial prejudice and its oppressive nature, this song highlights the link between law and music. This, and Holiday's own experience with the law because of this song prove the claim that music was used by Black women as a coping mechanism.

Nina Simone had a larger repertoire of protest music which, to an extent to the demise of her career, she used as a weapon of resistance, not only for reflection. During the Civil Rights Movement, Nina Simone moved from being just a jazz performer to being a mouthpiece of expression on the subjects of the plight of Black people and of women. She has been described as a 'staunch Civil Rights activist' for songs such as Mississippi Goddam, Young, Gifted and Black, Four Women and Why (the King is Dead). ${ }^{113}$ Regarding the first instance, a notable song is Why (The King of Love Is Dead). ${ }^{114}$ This song was written following the assassination of Dr ML King Jr. ${ }^{115}$ The song asks, rhetorically, about his death - why he was, and had to be, killed. The subject of Dr King is an important one in any discussion of racial prejudice in the USA. Therefore, by singing such a song, Simone may have done so for the cathartic value for herself, as she admits; ${ }^{116}$ however, this song is also an important form of protest against racial prejudice and a reminder that racial prejudice continued.

Nina Simone's other important song, for this article, is Four Women. ${ }^{117}$ Four Women is also written in a minor key, the key of

113 Nina Simone Biography (n 99 above).

114 N Simone Why (The King of Love Is Dead) (1967).

115 Nina Simone Biography (n 99 above).

116 See the autobiographic documentary 'What Happened Miss Simone?' by Liz Garbus (2015).

117 N Simone Four Women (1966). 
A minor, with Simone at the piano and the simple support of drums and bass. Through the song, Simone discusses four different Black women and their experiences with racial and patriarchal oppression. In the song, we meet Aunt Sarah, who is from the age of slavery, Saffronia, a product of rape who stands between slavery and Jim Crow, Sweet Thing, who is from the Jim Crow era and Peaches who represents all these women, but is also from an era after them all. In each verse, Simone eloquently describes the plights of Black women, as they existed during these different eras. A consideration of her lyrics for the whole song evokes a discussion about the establishment, and a need for the establishment, of Black Feminist Thought. All the issues discussed within this song are peculiar to Black women. More than this, they recognise the Black woman - they see her, and her plight.

Although in the beginning Simone had support from a more diverse crowd, when her songs became more political, the white patrons withdrew their support. ${ }^{118}$ This makes her case similar to that of Holiday, her protest music was impactful; however, this impact had negative effects on their careers. This evokes the uncomfortable thought that, had life been kinder to Eleanora and Eunice, we may have never had Billie and Nina - because the contents of their songs were heavy with oppressive themes, which they have personally experienced, but thousands were able to relate to. That oppression, especially at the hands of the white population, led to the demise of their careers makes Ma Rainey's words 'White folks don't understand the blues. They hear it come out, but they don't know how it got there,119 true for the music of these Black women too. As entertainment, their music was acceptable; however, as a form of protest, it was unacceptable.

Finally, from the American artists sampled here, of importance to illustrate the continuity of the Black woman's plight is Beyoncé's Formation. ${ }^{120}$ Formation was released in 2016, after the devastating Hurricane Katrina hit New Orleans. Regarding this song, it is not so much the lyrics as it is the accompanying music video which is of great importance. Although, it is interesting to note that this song too is written in a minor key, $\mathrm{F}$ minor. ${ }^{121}$ In her video, Beyoncé includes

118 (n 118 above).

119 The New Yorker 'Rhythm and Blues: "Ma Rainey" and August Wilson's mighty music' 10 February 2003 https://www.newyorker.com/magazine/2003/02/17/ rhythm-and-blues (accessed on 3 August 2020).

120 BG Knowles-Carter Formation (2016).

121 In addition to the strong, sad or regretful emotions often evoked by songs written in minor key signatures, it must be mentioned here that this song became even more 'Black' when Beyoncé performed it in the theme of Historically Black Colleges and Universities with a full marching band, with strong brass and drumlines at her Afropunk headlining performance (where she was the first Black woman to headline the festival). See: 'Homecoming: A Film by Beyoncé' by Beyoncé Knowles-Carter (2019). 
imagery of the devasted community, dilapidated surroundings including lost homes, schools and businesses. Finally, there are images of brutality and of neglect of the Black community, which was in need of assistance. In line with the rest of her album, 'Lemonade', Beyoncé also highlights the issues faced specifically by Black women. Therefore, Formation shows us that, even decades after the eras and movements discussed above, oppression persists, and music continues to be a form of protest against the oppressions discussed by Black women.

\subsection{Rondo: Sampled music by South African artists}

It should be mentioned here that, in addition to the shared experiences of Black women in the USA and South Africa, there is also common ground musically. In fact, anthropologists and ethnomusicologists have interpreted South African jazz as 'a hybrid from combining aspects of African American music and indigenous performance practices'. ${ }^{122}$ Furthermore, music in South Africa, especially during apartheid, was also an important tool of activism. Titlestad has written that, the very interconnection of different styles which were amalgamated to make South African jazz was 'in its very emphasis, a critique of apartheid'. 123

Three key figures are selected here too, namely, Letta Mbulu, Tandie (sometimes also spelt as Thandi) Klaasen and Thandi Ntuli. First is Letta Mbulu, who wrote Amakhamandela (Not Yet Uhuru) in 1994. This was a key turning point in South African history as it marked the official end of the Apartheid era. The first two stanzas of the song go as follows:

(u)Mhlaba wakithi bo (Oh, our land)

Usemi ndawonye (remains at a standstill)

Akukho mehluko kulelizwe (there is no change in this nation)

Qhawul'amakhamandela (loose/break the chains)

Ah thin'asina voti (ah, we do not have a vote)

Silal'emikhukhwini (we sleep in shacks)

Akukho mehluko kulelizwe (there is no change in this nation)

Qhawul'amakhamandela (loose/break the chains). ${ }^{124}$

This song, which Mbulu released in 1994, spoke to a South Africa which was promised freedom then; and continues to speak to such a South Africa even today. The song essentially speaks about a yearning to be

122 M Titlestad 'Jazz discourse and black South African modernity, with special reference to “Matshikese"” (2005) 32(2) American Ethnologist 210.

123 Titlestad (n 122 above) 211.

124 L Mbulu Not yet uhuru (1994). 
free vying with a yearning to withhold freedom - and this message is encapsulated almost entirely in these first two stanzas. In the song, there are those who are longing for and pointing out all the things which are still serving as a hindrance to attaining freedom; while others, those whom the grievances are being voiced to, are responding 'not yet uhuru'. Mbulu also does a good job of highlighting some problems which the Black people faced - the same problems which made them call for the end of apartheid - the chains, poor living conditions, no suffrage. Most importantly, she highlights the continued presence of these chains.

Interestingly, this song is still relevant in the 'new' South Africa. The governments may have changed, and the colour thereof; however, a lot of these problems and struggles still exist today. Thus, it is suggested that, whereas this song applied in a racially divided South Africa almost 30 years ago, it now applies to a South Africa divided in terms of class. Yes, on paper people have the vote, but that is not the issue. The issue is that, notwithstanding the right to vote being extended to the Black community, all the hopes which were attached to the rallying for this right, are still not being realised or seen to by even this new government. In other words, it is still 'not yet uhuru' because many Black people still live in shacks, have an ineffective vote, are still chained- economically speaking, for example - and for them, there is, or has been, no change in the land. This is a sad reality of many Black souls here in South Africa. It is especially regrettable for the Black woman who, because of this reality, has to struggle against the anger of the Black man, as formed by social dynamics.

Thandi Mpambane Klassen was a 'great' from Sophiatown. ${ }^{125}$ Tandie Klaasen's notable song is her Sophiatown. ${ }^{126}$ Sophiatown was a very important Black suburb in Johannesburg which was destroyed during apartheid, ${ }^{127}$ for its centrality to black identity. Sophiatown was used as a meeting place for fun as well as discussions of politics during Apartheid. ${ }^{128}$ In her melancholic, and surprisingly written in the key of C major, Sophiatown, Klaasen recalls her home, Sophiatown, and how the Apartheid government took it apart. Klaasen recalls:

125 M Rörich 'Shebeens, Slumyards and Sophiatown. Black women, music and cultural change in urban South Africa c 1920 - 1960' (1989) 31(1) The World of Music 95.

126 T Klaasen Sophiatown (1996).

127 Rörich (n 125 above) 100.

128 See generally: Rörich (n 125 above). 


\section{I can see my past passing by}

I had no chance to say goodbye to romance

I had no time to leave it all behind

It was a place I knew, where my dreams came true

Until they broke it down, Sophiatown

[...]

I can see police on a winter night

Breaking down the place where I was born.

This recollection may be personal; however, in the general sense it highlights the violence of the apartheid era, from the perspective of a Black woman. While, on a personal level, this song may be an outlet for pain, the general contribution of this song to the rest of us is a lesson about the violence of the Apartheid era. Forced removals of whole communities during the Apartheid era were not uncommon; however, the complete demolition of Sophiatown, not only as a place of residence and business, but also as a place of importance for the Black identity and resistance movement, raises its own issues.

Finally, to express the continued dual oppression of Black women in South Africa, reference is now made to Thandi Ntuli's New way. ${ }^{129}$ Ntuli's New Way comes off of her 2018 album titled 'Exiled', which she described as 'grappling with the traumas that have been experienced in the pasts, traumas we have not healed from. All this leaves us feeling displaced and exiled. ${ }^{130}$ It is so timely, true and important within this current climate of 'reconciliation', 'transformation' and 'decolonisation'. Whereas there are efforts to highlight the need for conversations around these themes, the silencing of these utterances is just as present. From the point of view of a Black woman, Ntuli writes:

Why can't we tell the truth about how it feels?

Perhaps, we are afraid that if we say too much, it might become real?

Yet, here we are, trapped by all these insincerities.

I wear a smile, bow down to serve your insecurities.

This could be the start of a new way,

You stand by me, and say that it is okay.

And let me be broken and hurting, process my healing.

Let me cry, release all of this pain.

129 T Ntuli New Way (2018).

130 'Full Concert: South African songbook - jazz at Lincoln Centre Orchestra with Wynton Marsalis' 24 March 2020 https://www.youtube.com/watch?v=VOJxZm gnpkA (accessed on 2 August 2020). 
You're free to stay, free to walk away.

But don't dare say that 'it's been a while now, move on from the past, child'.

The two stanzas repeated above reveal themes of racial and patriarchal prejudice as well as the added trouble of being silenced. When the song continues, it mentions younger people demanding 'the same as these old folk' and refers to the taking of land, diamonds and gold and the taking of dignity and healing. Ntuli eloquently uses metaphors to refer to both racial injustices as well as sexism throughout the piece. Therefore, she emphasises the interconnectedness, intersectionality and inseparability of the oppressions of racial prejudice and patriarchy for the Black woman. In doing so, in one song, Ntuli exposes the bottom line arguments of this paper: that Black women suffer dual oppression and they use that dual oppression as a subject of their music; and in so doing, they remind us that the law does not exist in a vacuum - it applies to and has consequences for people. Alas, she also exposes the seemingly everlasting nature of this dual oppression.

\section{Conclusion: Cadence}

In concluding this article, a few things should be highlighted. Firstly, the argument that the Black woman suffers injustices as a Black person and as a woman simultaneously. In both spaces, those which rally against racism and those which rally against sexism, far too often, she is neither central nor is she protected. As a result of this, her experiences have moved her towards Black Feminist Thought, which places her experiences as a woman and as a Black person, at the centre of the issues, discussions and resolutions. Moreover, this Black Feminist Thought also does not require her to choose between addressing issues of racism or addressing issues of sexism. Finally, Black women have written songs which have been a personal catharsis for them, and very often for us, but have also been a form of protest. I am inclined to say that the music discussed above, and all other music written in its style, is an extension of Black Feminist Thought, if not the musical form of Black Feminist Thought. Most importantly, there is a link between the law and the people to whom it applies, again, the law does not exist in a vacuum. Therefore, when promulgating or amending laws, we should be mindful of this. The law should never oppress, it should always protect. 